\title{
KONSEP DIRI GURU DAPAT MEMPENGARUHI KINERJA GURU DI SEKOLAH DASAR NEGERI SAWAH 2 CIPUTAT
}

\author{
Mirna Herawati \\ Dosen Program Studi Pendidikan Ekonomi Universitas Indraprasta PGRI \\ E-mail : mirnathar19@gmail.com
}

\begin{abstract}
Abstrak
Penelitian ini bertujuan untuk mengetahui adanya pengaruh yang signifikan konsep diri Guru terhadap kinerja Guru di SD Negeri Sawah 2 Ciputat. Metode penelitian yang digunakan dalam penelitian ini adalah metode kuantitatif. Sumber data yang digunakan adalah Guru di Sekolah Dasar Negeri Sawah 2 Ciputat dengan responden sebanyak 32 Guru. Teknik dalam pengumpulan data yang digunakan dalam penelitian ini adalah menggunakan kuesioner (angket). Dari hasil perhitungan nilai korelasi product moment sebesar $\mathrm{r}=0,527$ berada dalam skala yang sedang dan perhitungan koefisien determinasi yang hanya memberikan kontribusi konsep diri terhadap kinerja Guru hanya sebesar 27,80 \%. Kemudian hasil dari pengujian hipotesis menunjukkan nilai $\mathrm{t}_{\text {hitung }}>\mathrm{t}_{\text {tabel }}$ atau 2,461 $>1,695$. Sehingga disimpulkan bahwa terdapat pengaruh yang sangat signifikan konsep diri terhadap kinerja Guru di Sekolah Dasar Negeri Sawah 2 Ciputat.
\end{abstract}

Kata kunci : konsep diri Guru, kinerja Guru

\section{PENDAHULUAN}

Pendidikan merupakan faktor utama dalam pembentukan pribadi manusia. Pendidikan sangat berperan dalam membentuk baik buruknya pribadi manusia menurut ukuran normatif. Menyadari akan hal tersebut, Pemerintah sangat serius menangani bidang pendidikan, sebab dengan sistem pendidikan yang baik diharapkan muncul generasi penerus bangsa yang berkualitas dan mampu menyesuaikan diri untuk hidup bermasyarakat, berbangsa dan bernegara.

Reformasi pendidikan merupakan respon terhadap tintutan global sebagai suatu upaya untuk mengadaptasi sistem pendidikan yang mampu mengembangkan sumber daya manusia untuk memenuhi tuntutan jaman yang sedang berkembang. Melalui Reformasi pendidikan, pendidikan harus berwawasan masa depan yang memberikan jaminan bagi perwujudan hak-hak asasi manusia untuk mengembangkan seluruh potensi dan prestasinya secara optimal guna kesejahteraan hidup dimasa depan.

Untuk menjadi guru yang professional, seorang pendidik harus mengetahui hakikat pendidik (guru). Pendidik (guru) adalah mereka yang dengan sengaja mempengaruhi peserta didik agar meraih kedewasaan. Mereka harus memiliki: kompetensi (ilmu, keterampilan), sikap, dan kewibawaan.

Guru adalah salah satu unsur manusia dalam proses pendidikan. Dalam proses 
pendidikan di sekolah, guru memegang tugas ganda yaitu sebagai pengajar dan pendidikan. Sebagai pengajar guru bertugas menuangkan sejumlah bahan pelajaran ke dalam otak anak didik, sedangkan sebagai pendidik guru bertugas membimbing dan membina anak didik agar menjadi manusia susila yang cakap, aktif, kreatif dan mandiri. Djamarah ( 2002:27) berpendapat bahwa "baik mengajar maupun mendidik merupakan tugas dan tanggung jawab guru sebagai tenaga professional”. Oleh sebab itu, tugas berat sebagai seorang guru pada dasarnya hanya dapat dilaksanakan oleh guru yang memiliki kompetensi profesional yang tinggi.

Guru memegang peranan sentral dalam proses belajar mengajar, sehingga mutu pendidikan di sekolah sangat ditentukan oleh kemampuan yang dimiliki guru dalam menjalankan tugasnya.

Menurut Aqib (2002:35) guru adalah “faktor penentu bagi keberhasilan pendidikan di sekolah, karena guru merupakan sentral serta sumber kegiatan belajar mengajar”. Lebih lanjut dinyatakan bahwa guru merupakan komponen yang berpengaruh dalam peningkatan mutu pendidikan sekolah. Hal ini menunjukkan bahwa kemampuan atau kompetensi professional dari seorang guru sangat menentukan mutu pendidikan.

Pada dasarnya tingkat kompetensi professional guru dipengaruhi oleh faktor dari dalam guru itu sendiri yaitu bagaimana guru bersikap terhadap pekerjaan yang diemban. Sikap guru terhadap pekerjaan mempengaruh tindakan guru tersebut dalam menjalankan aktivitas kerjanya. Bilamana seorang guru memiliki sikap positif terhadap pekerjaannya maka sudah barang tentu guru akan menjalankan tugas fungsi dan kedudukannya sebagai tenaga pengajar dan pendidik di sekolah dengan penuh tanggung jawab. Demikian pula sebaliknya seorang guru yang memiliki sikap negatif pada pekerjaannya pasti dia hanya menjalankan fungsi dan kedudukannya sebagatas rutinitas belaka. Sehingga perlu ditanamkan sikap positif guru terhadap pekerjaannya mengingat peran guru dalam lingkungan pendidikan sangat sentral.

Guru adalah pendidik professional dengan tugas utama mendidik, mengajar, membimbing, mengarahkan, melatih, menilai, dan mengevaluasi peserta didik pada pendidikan anak usia dini jalur pendidikan formal, pendidikan dasar dan pendidikan menengah. 
Sikap guru terhadap pekerjaan dapat dilihat dalam bentuk persepsi dan kepuasannya terhadap pekerjaan maupun dalam bentuk motivasi kerja yang ditampilkan. Guru yang memiliki sikap positif terhadap pekerjaan, tentu akan menampilkan persepsi dan kepuasan yang baik terhadap pekerjaannya serta memiliki motivasi kerja yang tinggi, dan akhirnya akan mencerminkan seorang guru yang mampu bekerja secara professional dan memiliki kompetensi profesional yang tinggi.

Kinerja guru dapat dipengaruhi oleh beberapa faktor, selain kemampuan guru yang tertuang dalam kompetensi profesional juga faktor lain yaitu konsep diri guru yang menentukan keberhasilan guru dalam kinerjanya.

Salah satu faktor internal lain adalah konsep diri guru. Orang ingin melakukan perilaku dengan cara yang sesuai dengan konsep diri ini. Individu yang mempunyai konsep diri yang kuat dan positif akan memandang dunia dengan cara yang berbeda dengan orang yang mempunyai konsep diri yang lemah “ (Rita L.Atkinson,dkk, 1993:169).

Dengan demikian dapat diartikan bahwa konsep diri mempengaruhi sikap, pemikiran dan tindakan kita, serta suasana hati kita seperti rasa gembira dan rasa puas. Ada pendapat yang mengatakan bahwa. Taraf kepuasan yang orang-orang peroleh dari pekerjaan sebanding dengan tingkat dimana mereka telah sanggup mengimplementasikan konsep-konsep dirinya.

Konsep diri yang buruk akan membuat kita sulit merealisir bakat dan potensi yang terpendam dalam diri kita. Sebaliknya citra diri yang sehat melepangkan jalan untuk meraih sukses dan kebahagiaan dalam hidup. Sejalan dengan pikiran ini guru yang mempunyai konsep diri yang positif akan melapangkan kesuksesannya dalam belajar sedangkan yang memiliki konsep diri yang negatif akan mengalami kesulitan.

Berdasarkan hal diatas maka peneliti tertarik ingin meneliti tentang “Konsep Diri dapat Mempengaruhi Kinerja Guru di Sekolah Dasar Negeri Sawah 2 Ciputat”.

Adapun dari tujuan penelitian ini adalah untuk mengetahui konsep diri Guru terhadap kinerja Guru di Sekolah Dasar Negeri Sawah 2 Ciputat. 


\section{TINJAUAN PUSTAKA}

\section{Pengertian Kinerja}

Kinerja adalah sebuah kata dalam bahasa Indonesia dari kata dasar "kerja" yang menterjemahkan kata dari bahasa asing prestasi. Bisa pula berarti hasil kerja. Pengertian Kinerja dalam organisasi merupakan jawaban dari berhasil atau tidaknya tujuan organisasi yang telah ditetapkan. Para atasan atau manajer sering tidak memperhatikan kecuali sudah amat buruk atau segala sesuatu jadi serba salah. Terlalu sering manajer tidak mengetahui betapa buruknya kinerja telah merosot sehingga perusahaan/ instansi menghadapi krisis yang serius. Kesan-kesan buruk organisasi yang mendalam berakibat dan mengabaikan tanda-tanda peringatan adanya kinerja yang merosot.

Malayu S.P. Hasibuan (2003:34) mengemukakan “kinerja (prestasi kerja) adalah suatu hasil kerja yang dicapai seseorang dalam melaksanakan tugas yang dibebankan kepadanya yang didasarkan atas kecakapan, pengalaman dan kesungguhan serta waktu”.

Kinerja yaitu suatu kegiatan atau aktivitas yang berhubungan erat dengan tiga aspek pokok yaitu perilaku, hasil dan efektivitas organisasi. Perilaku menunjukkan suatu kegiatan untuk mencapai tujuan, efektivitas merupakan langkah-langkah dalam pertimbangan hasil kerja, organisasional menekankan pada aspek proses kerja.

Berhubungan dengan kinerjanya maka guru memiliki kinerja yang baik ada yang memiliki kinerja yang kurang baik. Guru yang memiliki kinerja baik sering disebut guru yang profesional sedangkan pengertian kinerja dalam Kamus Besar Bahasa Indonesia bahwa kinerja itu sesuatu yang diraih atau dicapai, prestasi yang diperhatikan, kemampuan kerja.

\section{Kinerja Guru sebagai Performansi dalam pembelajaran.}

Guru yang memiliki kinerja yang baik dan profesional memiliki beberapa kemampuan antara lain : (1) Guru harus memiliki ketrampilan untuk mendiagnosis siswanya dalam hal kemampuan, perhatian dan kepribadian, (2) Guru harus mengetahui bahwa guru itu bekerja dengan siswa, (3) Guru harus mengetahui berbagai metode yang efektif untuk membuat setiap siswa mencapai prestasi yang optimal, (4) Guru harus memiliki pemahaman yang luas terhadap tujuan pendidikan.

Menurut Richey (1973:95) Guru yang profesional memiliki kualitas mengajar yang tinggi, ada lima variabel yang menandai kualitas mengajar yang tinggi yaitu membuat perencanaan dan persiapan mengajar, menggunakan alat peraga dalam mengajar dan 
mengikut sertakan dalam berbagai pengalaman baru yang tinggi yakni :

1) Bekerja dengan siswa secara individu, meliputi (1) memberi tugas secara individual, (2) pekerjaan peserta didik segera diperiksa dan segera dikembalikan, (3) hubungan antara guru dan siswa sangat akrab, (4) percakapan antara guru dan siswa sering dilakukan untuk menolong siswa.

2) Perencanaan dan persiapan mengajar, meliputi (1) membuat perencanaan dan strategi belajar, (2) mengadakan praktek lapangan,

3) pengetahuan guru adalah merupakan sumber belajar dan ditambah buku penunjang lainnya, materi pelejaran yang esensial selalu disajikan.

4) Penggunaan alat peraga meliputi (1) guru memberi tugas dan ketrampilan yang berhubungan dengan alat-alat praktek mengajar, (2) guru selalu memanfaatkan buku pelajaran, (3) guru memberi tugas yang terkait dengan buku perpustakaan.

5) Mengikutsertakan siswa dalam berbagai pengalaman belajar, meliputi : (1) guru memberi tanggungjawabnya kepada siswa dalam tugas-tugasnya. (2) guru mengikutsertakan siswanya dalam menyususn rencana pembelajaran, (3) guru menyajikan bermacam-macam pengalaman belajar, (4) guru memberi motivasi belajar kepada peserta didik.

6) Kepemimpinan aktif guru meliputi (1) membantu peserta didik dalam memecahkan masalah, (2) memberi kesempatan kepada peserta didik untuk menjadi pemimpin, (3) mendayagunakan permainan sebagai media belajar (4) memberi kesempatan kepada siswa untuk berdiskusi dan mengemukakan pendapatnya.

Menurut Gordon dan Burch (1997:381) guru yang profesional atau guru yang mempunyai kinerja yang tinggi adalah guru yang efektif dalam menjalin hubungan dengan peserta didik sehingga terjadi saling pengertian, saling percaya antara kedua belah pihak. Lebih lanjut Gordon mengemukakan bahwa guru yang efektif adalah guru yang memiliki ciri-ciri sebagai berikut : (a) lebih mengutamakan pesan saya daripada pesan anda, (b) memilih metode menang-menangan dalam menyelesaikan konflik, (c) selalu menggunakan bahasa penerimaan dan menghindari bahasa penolakan (d) berdoa dan pasrah kepada Allah SWT bila semua usaha yang ditempuh namun permasalahan tetap belum selesai. 


\section{Kinerja Guru sebagai Prestasi dalam Pembelajaran.}

Standar prestasi kerja guru adalah minimal yang wajib dilaksanakan guru dalam proses pembelajaran dan bimbingan. Standar Prestasi Kerja Guru tersebut meliputi :

1) Penyusunan Program Pembelajaran terdiri dari:
a) Analisis Materi Pelajaran (AMP)
b) Program Tahunan (Prota)
c) Program Semester (Promes)
d) Program Satuan Pembelajaran (PSP)
e) Rencana Pembelajaran (RP)
f) Alat evaluasi (AE)
g) Program Perbaikan dan pengayaan
h) Program Bimbingan Konseling

2) Pelaksanaan Program Pembelajaran, meliputi :
a) Pelaksanaan pembelajaran di kelas
b) Penggunaan strategi pembelajaran
c) Penggunaan media dan sumber belajar

3) Pelaksanaan Evaluasi, meliputi :
a) Evaluasi hasil belajar
b) Evaluasi pencapaian target kurikulum
c) Evaluasi daya serap.

4) Analisis evaluasi, meliputi :
a) Analisis ketuntasan belajar
b) Analisis butir soal

5) Pelaksanaan Perbaikan dan Pengayaan, meliputi :

a) Pelaksanaan perbaikan pembelajaran

b) Pelaksanaan pengayaan pembelajaran.

Berdasarkan beberapa teori yang sudah dikemukakan dapatlah disimpulkan bahwa kinerja guru akan dapat ditingkatkan dengan melakukan perencanaan program pembelajaran yang sesuai dengan program yang direncanakan, diadakan evaluasi pembelajaran dan pelaksanaan perbaikan dan pengayaan pembelajaran itu. 


\section{Konsep Diri Guru}

Konsep diri adalah gambaran seseorang mengenai dirinya sendiri. Konsep diri seseorang erat berhubungan dengan penerimaan dirinya, penilaian dirinya , citra dirinya, gambaran tentang dirinya dan tentang harga dirinya.Konsep diri seseorang dari waktu ke waktu akan mengalami perkembangan. Semakin luas, semakin beragam dan kaya pengalaman maka akan semakin terinci serta mantap pola konsep dirinya.

Definisi konsep diri yang lain adalah " those physical, social, and psychological perceptions of ourselves that we have derived from experiences and our interaction with others” (William D. Brooks, 1974:40 dalam Jalaludin Rakhmat, 2003: 99).

Konsep diri adalah pandangan dan perasaan kita tentang diri kita, persepsi tentang diri ini boleh bersifat psikologi, sosial dan fisik.

\section{Pembentukan, Pertumbuhan dan Perkembangan konsep diri.}

Diri pribadi adalah struktur intrapsikis yang bertumbuh sesuai prinsip tertentu., dari segi dinamis dapat dibedakan dua struktur diri, yaitu Diri Ideal dan Diri Aktual. Diri Ideal merupakan dinamika harapan dan dasar referensi untuk menghadapi realita. Tergantung pada tahap kedewasaan yang dicapai maka diri ideal ini dapat berciri primitif dan irealis, atau dewasa dan adekwat.

Diri aktual sebaliknya menunjuk pada kenyataan disposisi yang telah dicapai perkembangan dandapat dibedakan antara aktual tampak yaitu aktual yang disadari sendiri dan aktual laten yaitu ciri pribadi yang tidak ia kenal sendiri.

Diri Aktual ini juga tergantung dari tahap pertumbuhan yang sedang dicapai, semakin dewasa maka lebih realistislah Diri Aktual tampak, dan makin sedikitlah pengaruh diri laten. Dengan demikian gambaran diripun bukan pengertian yang statis tetapi dinamis.

Dinamika ini berdasar pada interaksi tiga factor yaitu : " faktor bawaan, faktor sosial, faktor persepsi ” (F. Mardi Prasetyo,SJ, 2000: 168). Pertumbuhan dan perkembangan gambaran diri berlangsung melalui tahap-tahap sebagai berikut ” tahap autisi atau indiferensi, tahap simbiotik, tahap diferensi, tahap integrasi, tahap konsolidasi ” (F. Mardi Prasetyo, SJ, 2000: 172) 


\section{Faktor-faktor yang mempengaruhi konsep diri.}

Sejumlah faktor yang mempengaruhi konsep diri antara lain :

1) Jenis Kelamin

Stereotipe sosial yang muncul dalam masyarakat memegang peranan penting dalam menentukan bagaimana seorang pria atau wanita bertindak dan berperasaan.

2) Harapan-harapan

Stereotipe sosial mempunyai peranan penting dalam menentukan harapanharapan apa yang dipunyai oleh individu terhadap dirinya sendiri dimana harapan terhadap dirinya sendiri itu merupakan pencerminan dari harapan-harapan orang lain terhadap dirinya.

3) Suku bangsa

Dalam masyarakat yang heterogen terdapat beberapa kelompok masyarakat. Kelompok masyarakat ini ada yang dianggap minoritas dan ada yang merasa mayoritas. Apabila kelompok minoritas tidak menunjukkan kelebihannya dari kelompok mayoritas maka kelompok minoritas cenderung memperkembangkan konsep diri yang negatif.

4) Nama dan pakaian

Nama dan pakaian juga berpengaruh terhadap individu dalam memperkembangkan konsep dirinya.

5) Tingkat pendidikan dan pekerjaan

Individu yang memiliki tingkat pendidikan yang tinggi dan berasal dari lembaga pendidikan yang terpandang cenderung memperkembangkan konsep diri yang positif.

\section{Manfaat konsep diri}

Apabila konsep diri sesuai dengan keadaan yang sebenarnya maka akan memudahkan individu untuk berinteraksi dengan lingkungannya dalam pergaulannya dengan orang lain.

Pengaruh Konsep Diri pada Komunikasi Interpersonal

Sukses komunikasi interpersonal banyak bergantung pada kualitas konsep diri seorang guru; positif atau negatif adapun tanda-tanda konsep diri yang positif dan negative. Ada empat tanda orang yang memiliki konsep diri negatif yaitu :

1) Peka pada kritik, 
Orang ini sangat tidak tahan terhadap kritik yang diterimanya, dan mudah marah atau naik pitam, koreksi seringkali dipersepsi sebagai usaha untuk menjatuhkan harga dirinya. Dalam komunikasi cenderung menghindari dialog terbuka, dan bersikeras mempertahankan pendapatnya dengan berbagai logika yang keliru.

2) Responsif sekali terhadap pujian

Walaupun mungkin berpura-pura menghindari pujian ia tidak dapat menyembunyikan antusiasmenya pada waktu menerima pujian, bersamaan dengan kesenangannya terhadap pujian merekapun bersikap hiperkritis terhadap orang lain, selalu mengeluh, mencela atau meremehkan apapun dan siapapun.

3) Merasa tidak disenangi orang lain

Ia merasa tidak diperhatikan, orang lain dianggap sebagai musuh, sehingga tidak dapat melahirkan kehangatan dan keakraban persahabatan, menganggap dirinya sebagai korban dari sistem sosial yang tidak beres.

4) Pesimis terhadap kompetisi

Enggan bersaing dengan orang lain dalam membuat prestasi, menganggap tidak akan berdaya melawan persaingan yang merugikan dirinya. Sebaliknya orang yang memiliki konsep diri positif ditandai dengan lima hal sebagai berikut :

a) Ia yakin akan kemampuan mengatasi masalah

b) Ia merasa setara dengan orang lain

c) Ia menerima pujian tanpa rasa malu

d) Ia menyadari bahwa setiap orang mempunyai berbagai perasaan, keinginan dan perilaku yang tidak seluruhnya disetujui masyarakat

e) Ia mampu memperbaiki dirinya karena ia sanggup mengungkapkan aspek-aspek kepribadian yang tidak disenanginya dan berusaha mengubahnya.

Dalam kenyataannya memang tidak ada orang yang betul-betul sepenuhnya berkonsep diri negatif atau positif, tetapi untuk efektivitas komunikasi interpersonal sedapat mungkin kita memperoleh tanda-tanda konsep diri yang positif.

Mengenai proses terbentuknya dan perkembangan konsep diri rupanya tidak ada kesatuan pendapat di kalangan ahli psikologi, hal ini sangat tergantung kepada bagaimana seseorang merumuskan diri (self) itu sendiri. Oleh karena itu jika dipertanyakan faktor-faktor apa yang mempengaruhi perkembangan kepribadian pada umumnya dan perkembangan konsep diri pada khususnya, hal ini bisa terjawab apabila 
diperhatikan perkembangan teori psikologi yang kemudian menyebabkan timbulnya tiga aliran besar yaitu : aliran empirisme, nativisme dan konvergensi. Aliran Konvergensi adalah aliran yang bersifat netral dibandingkan dua aliran lainnya, menurut aliran ini bahwa perkembangan konsep diri seseorang ditentukan oleh faktor pembawaan dan lingkungan.

Dari uraian di atas dapat diketahui bahwa konsep diri terbentuk karena adanya faktor internal yaitu faktor yang berasal dari dalam diri seorang itu sendiri misalnya persepsi dan penilaian terhadap dirinya sendiri, maupun faktor eksternal yaitu faktor yang berasal dari luar yaitu pandangan orang lain terhadap dirinya atau hal yang dipengaruhi oleh lingkungan dimana mereka berada

Untuk memperoleh data mengenai konsep diri guru maka diperlukan indikatorindikator sebagai petunjuk adanya konsep diri yang hendak diungkapkan dan diukur. Dalam penelitian ini digunakan alat evaluasi yang tepat yaitu disajikan dalam bentuk kisikisi yang mencakup empat aspek : aspek fisik, aspek psikis, aspek sosial dan aspek akademik (William D.Brocks dalam Jalaluddin Rachmat , 2003 : 99).

Aspek fisik meliputi : penerimaan terhadap bentuk tubuhnya, penampilannya, pandangannya mengenai bentuk-bentuk bagian tubuhnya, pandangan orang lain terhadap fisik dan penampilannya, kondisi tubuhnya, perasaan yang sering muncul bila berhadapan dengan orang lain.

Aspek psikhis meliputi : perasaan tentang keberadaan dirinya, sikap terhadap apa yang ada pada dirinya, kemauan yang sering muncul dari dalam dirinya dan berpikir tentang dirinya.

Aspek sosial meliputi : perasaan dirinya sebagai anggota masyarakat, hubungannya dengan teman, tanggapan orang lain tentang dirinya, kerjasama dengan orang lain, sikapnya terhadap apa yang telah dilakukannya dan apa yang dilakukan orang lain terhadap dirinya dan penampilannya di depan umum.

Aspek akademik meliputi : sikap terhadap pendidikan, sikap terhadap materi pelajaran, ilmu-ilmu pendidikan, kesadaran untuk belajar, menghargai nilai-nilai yang terkandung dalam pendidikan, perhatiannya terhadap buku-buku dan nilai yang dicapai dalam mata pelajaran. 


\section{METODE}

Metode penelitian merupakan cara yang digunakan oleh peneliti dalam mengumpulkan data. Metode dalam penelitian ini adalah metode penelitian deskriptif. Metode penelitian diskriptif adalah suatu metode yang digunakan dalam meneliti status kelompok manusia, suatu objek, suatu set kondisi, suatu sistem pemikiran maupun peristiwa pada masa sekarang. Tujuan penelitian deskriptif atau lukisan secara sistematis, faktual, dan akurat mengenai fakta-fakta, sifat-sifat atau fenomena yang diselidiki.

\section{HASIL DAN PEMBAHASAN}

\section{a. Menentukan Harga thitung}

Uji hipotesis yang telah dirumuskan diuji tingkat signifikannya dengan uji $t$ menggunakan rumus sebagai berikut :

$\mathrm{t}_{\text {hitung }}=\frac{r \sqrt{n-2}}{\sqrt{1-r^{2}}}$

Tabel 1. Coefficients

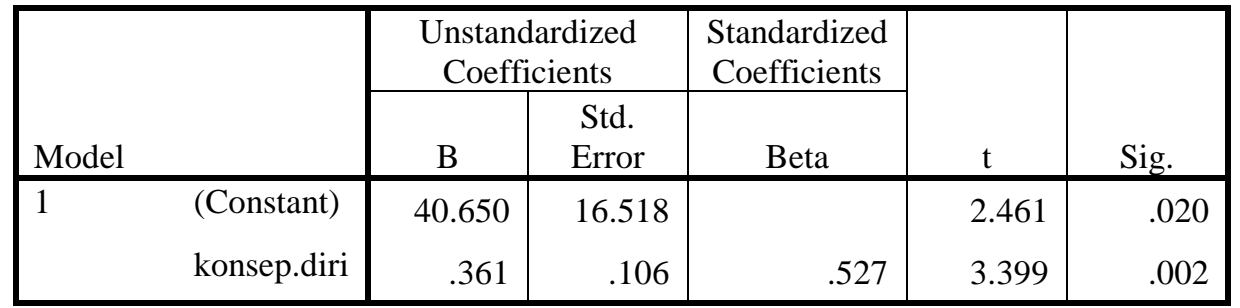

a. Dependent Variable: kinerja

Perhitungan thitung menggunakan SPSS Versi 2.1 seperti yang tertera pada tabel 1. yaitu $t_{\text {hitung }}$ sebesar 2,461

\section{b. Menentukan Harga tabel}

$\mathrm{t}$ tabel yang dicari pada $\alpha=5 \%$ uji dua pihak dengan $\mathrm{dk}=\mathrm{n}-1$. Nilai $\mathrm{t}$ tabel pada $\alpha=5 \%$ uji dua pihak dengan $\mathrm{df}=\mathrm{n}-1$ adalah 1,695 .

\section{c. Kriteria Pengujian}

Tolak $\mathrm{H}_{0}$ jika $t_{\text {hitung }}>\mathrm{t}_{\text {tabel }}$ dan terima untuk kriteria lainnya 


\section{d. simpulan}

Kriteria $t_{\text {hitung }}>\mathrm{t}_{\text {tabel }}(2,461>1,695)$ maka $\mathrm{H}_{0}$ ditolak dan $\mathrm{H}_{1}$ diterima pada $\alpha=0,05$.

Dengan demikian konsep diri Guru mempunyai pengaruh terhadap kinerja Guru.

\section{UCAPAN TERIMAKASIH}

Dengan ini penulis mengucapkan rasa syukur kepada Allah SWT yang telah memberikan rahmat dan hidayah-Nya, serta penulis mengucapkan terima kasih kepada Sekolah Dasar Negeri Sawah 2 Ciputat, serta ucapan terima kasih kepada semua pihak yang telah membantu.

\section{DAFTAR PUSTAKA}

Baltus Rita K. 1993. Personal Psychology for life and work. New York: Mc Graw-Hill Book Company

Djamarah, Syaiful B. 2002. Psikologi Belajar. Jakarta: Rineka Cipta.

Gordon T \& Burch, N. 1997. Teacher Effectivenes for Training, Terjemahan oleh Adhitya Kumara Dewi. Jakarta: PT Gramedia Pustaka Utama.

Hasibuan M. 2003. Manajemen Sumber Daya Manusia. Yogjakarta: BPFE.

Prasetyo, Mardi SJ.F. 2000. Unsur-unsur Hakiki dalam Pembinaan I, Yogyakarta: Kanisius

Rakhmat Jalaludin. 2003. Psikologi Komunikasi. Bandung: PT Remaja Rosdakarya.

Richey, R.W. 1973. Planning for Teaching and Introduction, Fourth Edition, Colorado: Mc Graw-Hill.

UU. RI. No. 20 Tahun 2003. Sistem Pendidikan Nasional. Jakarta: Asokadikta dan Durat Bahagia.

Zainal, Aqib. 2002. Profesionalisme Guru dalam Pembelajaran. Surabaya: Insan 